Dr FEDERICO FERRETTI - BA, MA, PhD, Associate Professor, University College Dublin, School of Geography, Belfield, Newman Building, Room H015, federico.ferretti@ucd.ie, https://people.ucd.ie/federico.ferretti tel. +353 1716 8176, +39 339 7972091; ORCID ID: 0000-0002-5446-6522; Scopus: 55540917000

\title{
Subaltern connections: Brazilian critical geographers, development and African decolonization
}

Abstract: This paper explores the relations to Africa and African decolonisation of three key figures in Brazilian critical geographies and development studies, Manuel Correia de Andrade (1922-2007), Josué de Castro (1908-1973) and Milton Santos (1926-2001). Based on the analysis of their works and unpublished archives, my main argument is that the radical Third World perspectives that these intellectuals expressed anticipated later critiques to ideas of development as a neocolonial device. Drawing upon current literature on decolonisation, international conferencing and anti-racist solidarity networks, I discuss these matters in relation to these authors' interest in cultural diversity and internal colonialism. Crucially, they developed this sensitivity in the Brazilian Northeast, a region especially shaped by AfroBrazilian and Indigenous cultural legacies. While supporting anti-imperialist nationalisms in the Third World, these Brazilian scholars fostered multilingual, internationalist and cosmopolite activism and scholarship. This is revealed by the study of the transnational networks that they developed during the exile and the various persecutions that many of them suffered after the 1964 military coup. I finally argue that these works can substantiate recent claims to 'decolonize' geography and development studies, at the condition that these fields of study take seriously their anti-imperial traditions and their 'voices from the South'.

Keywords: Third World Conferencing; Critical Geographies; Decolonization; Critical Development; Afro-Brazilian Cooperation

F. Ferretti, 2020, "Subaltern connections: Brazilian critical geographies and African decolonisation", The Third World Quarterly, early view: 
This paper addresses approaches to decoloniality and, more specifically, to African decolonization by a circuit of critical Brazilian geographers who experienced exile or various persecutions during the military dictatorship that ruled their country from 1964 to 1985 . In these years, they established worldwide scholarly and activist networks that are objects of recent studies, especially focussing on works by Manuel Correia de Andrade (1922-2007), Josué de Castro (1908-1973) and Milton Santos (1926-2001). ${ }^{i}$ However, most current scholarship focusses on their connections with Northern scholars, while less attention has been given to their South-South relations and their commitment to the 'Third World'. Nevertheless, this commitment was among their main concerns.

Based on exploration of these geographers' archives surviving at the Recife CEHIBRA-Fundaj and at the São Paulo Instituto de Estudos Brasilieros, this paper aims at filling this lacuna by addressing their original works and networks on African decolonization. This survey covers the period from 1956, when the Suez crisis was the occasion of an important de Castro anticolonial speech, to 1989, when de Andrade's book on Brazil and Africa was published and when the fall of the Berlin Wall symbolically inaugurated the process leading to the end of the Cold War, that is, the period when the very notion of 'Third World' was shaped. ${ }^{\text {ii }}$ My argument is twofold. First, I argue that the cultures and histories of these geographers' region, the Northeast of Brazil, the cradle of Afro-Brazilian social insurgence from the early times of the slave trade, ${ }^{\text {iii }}$ played a key role in informing their approaches to anti-colonialism and to the revolt of 'coloured' peoples. Second, while the traditional roles of geography as a science serving colonial empires have been discussed in all their complexity since classical contributions, ${ }^{\text {iv }}$ exploring anti-colonial and anti-racist aspects of the geographical traditions can serve current agendas for decolonizing both geography and development studies.

Extending and connecting scholarship on decolonization, on the geopolitics of development and on radical and subaltern geographies, this paper aims at bringing to the attention of current debates the contributions of these scholars, which go beyond their immediate impact at that time and can inform current understandings of development. The very notion of development came under scrutiny in the 1990s due to authors who questioned it as a Western cultural construction $^{\mathrm{v}}$ and called for the rediscovery of traditional and Indigenous knowledge. Similar

F. Ferretti, 2020, "Subaltern connections: Brazilian critical geographies and African decolonisation", The Third World Quarterly, early view: https://www.tandfonline.com/doi/full/10.1080/01436597.2020.1722095 
concerns underpin current scholarship on Latin American grassroots activism and the role of Indigenous notions such as Buen Vivir/Sumak Kawsay, ${ }^{\text {vi }}$ while recent work by Marcus Power highlights the use of Northern notions of development as part of counter-insurgency strategies in the Third World during the Cold War. ${ }^{\text {vii }}$ As I explain below, it is possible to argue that critical Brazilian geographers anticipated critiques of development without giving up the need to investigate class contradictions, hunger and poverty. ${ }^{\text {vii }}$

Scholarship on geographies of decolonization has highlighted the importance of the central decades of the twentieth century for understanding the complexity of cultures of decolonization beyond accounts based on economics. ${ }^{\text {ix }}$ My paper extends this literature by showing how early critical geographies can be considered as a constituting part of these cultures. Brazilian geographers participated in the 'cloud of disappointment'x, which followed the initial enthusiasm for decolonization, due to the lasting situation of economic dependency of most Third World countries. Paradoxically, some of their links with Africa, both Mediterranean and Sub-Saharan, came through their relations (and exile experiences) in 'Northern' places such as Paris, which was then 'an organizing centre for anti-colonial activity'xi especially associated with Black anti-racist networks. While notions on Black internationalism and solidarity have been recently addressed by geographers ${ }^{\mathrm{xii}}$ and by scholars focussing on insurgent cultures in the 'Black Atlantic' and 'Black Pacific', xiii some nonexclusionary notions of race have been analysed by recent studies on Third World decolonial conferences such as the 1955 Bandung Conference and the 1966 Tricontinental. There, inclusive notions of 'coloured peoples' underpinned 'a transnational alliance'xiv of anti-imperialist resistance. These debates are considered to have fostered a 'profound, anti-racist, anti-imperialist discourse [that] can be observed resurfacing in contemporary alter-globalization and social justice movements' ${ }^{\mathrm{xv}}$

Recent contributions on Bandung suggest that this conference had more important effects in the middle and long term rather than in its immediate outcomes, given that the heterogeneity of the positions represented impeded the approval of very radical deliberations. For instance, it has been observed that, while anti-imperialism was a principal theme of Bandung, not all the twenty-nine attending nations were former colonies. ${ }^{\text {xvi }}$ At that moment, most African nations were still colonized, and the importance of Bandung is considered to be a decisive encouragement 'to push for and assert their independence'xvii following the Asian example

F. Ferretti, 2020, "Subaltern connections: Brazilian critical geographies and African decolonisation", The Third World Quarterly, early view: https://www.tandfonline.com/doi/full/10.1080/01436597.2020.1722095 
(while Latin American nations were not represented). Race remained a key point in the discussions, leading scholars to consider that this conference 'has a life in the global history of antiracism'. ${ }^{x i i i}$ Even if many argued that its importance as a foundation for anti-imperialism was 'vastly overstated', xix Bandung played an important role in the imaginaries of decolonization, including those of the Brazilian geographers whose work is discussed here.

The Tricontinental Conference held in La Habana in 1966 was declaredly more radical than Bandung and included Latin American nations and delegates from militant groups beyond those of formal states. According to Anne Garland Mahler, the Tricontinental anticipated current notions of 'the Global South as a critical concept', ${ }^{\mathrm{xx}}$ in a sense akin to how Latin American MCD (Modernity-Coloniality-Decoloniality) authors define the 'Souths' as places of resistance. ${ }^{\text {xxi }}$ Recalling the historical 'black involvement and leadership'xxii in early Cuban decolonization, Mahler stresses an important difference between notions of race based on rather defined racial and cultural belongings in movements such as Pan-Africanism or Francophone Négritude and as Tricontinentalist ideas of race as 'metonymy'. That is, 'Colour remains an umbrella for a politics of anti-imperialism but does not necessarily denote the skin colour of the peoples included under that umbrella' xxiii Mahler finally argues that, today, more engagement on the relations between the Global South as 'a black internationalist political

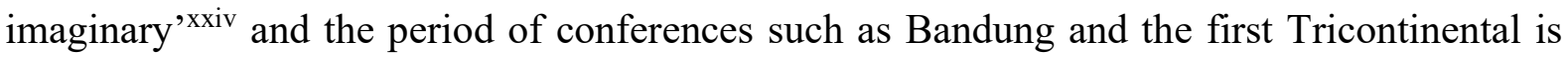
needed. As recently noticed by Archie Davies, ${ }^{\mathrm{xxv}}$ de Castro was an early correspondent and contributor to the journal Tricontinental, which matched his ideas of an insurgent Third World. The cases that I address shed new light in this direction.

In current debates on the decolonization of geographical scholarship, new attention is given to issues of inclusion in the discipline. ${ }^{\mathrm{xxvi}}$ A recent collective work on the spatial histories of radical geography posits the need to go beyond readings centred on North America, ${ }^{x x v i i}$ while another recent book on Subaltern Geographies highlights the importance of considering knowledge produced in places other than the traditional Western ones. ${ }^{\text {xxviii }}$ These works recall arguments by David Slater (1946-2016), a friend and collaborator of Milton Santos in Tanzania, who stressed the anti-colonial value of '[dependency] insurgent theory'xxix for allowing the South 'theorizing back' in opposition to ideas fabricated in the 'Global North'. Brazilian critical geographers notably contributed to these discussions, anticipating features of

F. Ferretti, 2020, "Subaltern connections: Brazilian critical geographies and African decolonisation", The Third World Quarterly, early view: https://www.tandfonline.com/doi/full/10.1080/01436597.2020.1722095 
pluriversalism, ${ }^{\mathrm{xx}}$ paralleling critical race studies which inspired postcolonialism ${ }^{\mathrm{xxxi}}$ and fostering ideas on social justice around which different cultures can engage decolonial dialogues.

Of course, we need to acknowledge the limitations of discourses that sometimes reproduced what is defined today as 'Western epistemes', including a certain faith in industrialisation and on the availability of natural resources, notions which are contested by current scholarship on Indigenous cosmovision, seeing 'nature' as a 'living and spiritual being' xxxii While NorthAmerican scholarship has importantly criticised 'moves to innocence'xxxiii in settler cultures and deemed the politics of Indigenous recognition 'cultural genocide', xxxiv some South American authors support 'critical interculturality' ${ }^{\mathrm{xxxv}}$ as an instrument of the de-colonial turn. Indigenous feminist scholars crucially argue that decolonisation should not only be a theory, but 'also a practice'. xxxi $Y$ et, early critical Brazilian geographers contributed to these moves in several ways, including their emphasis on praxis, chiming with claims that 'the road moves quicker than the academy, ${ }^{x x x v i i}$ and their interest in environment and Indigenous and AfroBrazilian traditions which still inspire Brazilian decolonial scholars. ${ }^{\text {xxxviii }}$

In the first part of my paper, I discuss de Andrade's 1989 key book on Brazil and Africa as both a synthesis and an introduction to the work performed by his friends Santos and de Castro, who were more directly involved with Africa in the previous decades. In the second part, I address de Castro's national and international networking, before and after his exile in 1964, trying to assemble social and anticolonial movements in all the Third World, with a special focus on Africa. In the third part, I address Milton Santos's professional experiences in SubSaharan Africa and his ideas on the challenges that a Black person from Bahia could face in this transnational trajectory.

\section{On Afro-Brazilian cooperation}

Throughout his remarkable career as a 'noble father' of Brazilian critical and radical geographies, ${ }^{\text {xxix }}$ Manuel Correia de Andrade focussed great attention on the Afro-Brazilian traditions of his region, the Nordeste, analysing early insurgences of Black slaves from the first quilombos to the struggles for abolition of slavery and emancipation. ${ }^{\mathrm{xl}}$ In Brazil, he was among the firsts who rediscovered alternative and anticolonial geographical traditions with his book

F. Ferretti, 2020, "Subaltern connections: Brazilian critical geographies and African decolonisation", The Third World Quarterly, early view: https:/www.tandfonline.com/doi/full/10.1080/01436597.2020.1722095 
on Elisée Reclus. ${ }^{\text {xli }}$ His 1989 work O Brasil e a Africa came relatively later in his career, but it represents a compendium of the positions assumed by Brazilian critical geographers on African decolonization, providing a first geographer's assessment of that period. De Andrade expressed anticolonial and anti-racist positions, writing about the European Conquista of his country and the subsequent 'genocide'xlii of Amerindians and denouncing how the Portuguese wittingly 'tried to exterminate the native population'. ${ }^{x}$ liii The 'fierce resistance' ${ }^{\text {xliv }}$ that they encountered resulted from both Indigenous and African slaves through experiences such as the Black Republic established in the quilombo of Palmares in the seventeenth century. De Andrade denounced how, although the African influence in the formation of Brazilian cultures was considerable, 'strong prejudices and discrimination'xlv lingered in Brazilian society. Therefore, intervening in the disputed spaces opened by African decolonization was a difficult challenge for Brazil if it wanted to be an ally of young African states 'against the domination of the big powers', ${ }^{x l v i}$ rather than a new neo-colonial and paternalistic power.

De Andrade did not have direct experience in African fieldwork, but he was acquainted with French scholars who were active supporters of African decolonization, such as geographer Jean Dresch, who helped him during his 1964-1965 sojourn in Paris following the military coup in Brazil. ${ }^{x l v i i}$ Moreover, de Andrade's archives show that he was a strong reader of international studies from Third-Worldists and decolonization leaders. ${ }^{x l v i i i}$ Politically, de Andrade's terminology was a radically anti-imperialist one; he defined the French-Algerian War as a struggle for 'liberation', xlix and while distinguishing between settler colonies and invaded colonies, he argued that colonization always 'distorted the economy in favour of the colonizer'. Sociologically, de Andrade exposed how the colonialists of different European nations tried to disorganize tribal lifestyle in Africa, placing different ethnic groups in mutual competition to divide and dominate them.

Anticipating arguments from the literature on decolonization mentioned above, de Andrade argued that decolonization was 'a heterogeneous process' "li and that political liberation did not imply the end of poverty and social contradictions. Importantly, de Andrade identified new (post)colonial geopolitical actors within the area. The first was South Africa, whose 'racist government ${ }^{\text {'lii }}$ he severely blamed for its politics of apartheid and its occupation of Namibia. The second was Israel, which represented a threat 'for Egypt's struggle for independence'liii

F. Ferretti, 2020, "Subaltern connections: Brazilian critical geographies and African decolonisation", The Third World Quarterly, early view: https://www.tandfonline.com/doi/full/10.1080/01436597.2020.1722095 
since the 1956 Suez crisis. De Andrade was not prejudicially anti-Israel, considering that he had visited the country in the 1960s seeking collaboration with Israeli scholars on matters of irrigation in dry lands. ${ }^{\text {liv }}$ However, he criticized Israel's role as a representative of Western powers, namely the Anglo-French in the Suez affair and later the United States.

Like Santos and de Castro, de Andrade refused essentialized views of development, arguing for instance that Tanzanian post-colonial leader Julius Nyerere sought "ways for the true development of his country', ${ }^{\mathrm{v}}$ implying that development was something different than mere economic growth. Anticipating current claims of Latin American critical scholarship, de Andrade argued that extractivism implied 'little advantage for natives'lvi and that underdevelopment served as a pretext for neocolonial interventions and for the "control of the economy by transnational corporations'. ${ }^{\text {lvii }}$ De Andrade identified Northern corporate interests as forces acting against full decolonization, attributing the assassination of Congolese panAfrican leader Patrice Lumumba to 'imperialist interests'. ${ }^{\text {lviii }}$ The former Portuguese colonies (Green Cape, Guinea Bissau, São Tomé e Príncipe, Angola and Mozambique) were of special interest for de Andrade, as unpublished writings surviving in his archives can confirm. ${ }^{\text {lix }}$ Among the last that obtained formal independence, these countries were seen in Brazil as possible economic and geopolitical allies. De Andrade wished that Brazil's influence could counter South Africa, whose imperialistic politics had consequences in Angola and Mozambique, in addition to the 'murdering of Black leaders' ${ }^{\text {' } x}$ in Botswana and Zimbabwe.

For de Andrade, these reactionary forces hindered the socialistic perspectives that independentist leaders of former Portuguese colonies 'such as Agostinho Neto, Amilcar Cabral and Samora Marcel'lxi had tried to foster. De Andrade quoted them together with other 'heroes' of decolonization, such as Lumumba, Guinean leader Sékou Touré, who had chosen to refuse economic cooperation with France after independence, Kwame Nkrumah in Ghana and Yomo Kenyatta in Kenya, who led guerrillas against the British. The author fully acknowledged the difficulties which decolonial struggles encountered before and after formal independencies, noticing the losses derived from the fact that some of the most radical leaders such as Cabral and Lumumba were soon assassinated.

F. Ferretti, 2020, "Subaltern connections: Brazilian critical geographies and African decolonisation", The Third World Quarterly, early view: https://www.tandfonline.com/doi/full/10.1080/01436597.2020.1722095 
On economics, de Andrade expressed a position akin to those of Latin American dependentistas, ${ }^{l x i i}$ arguing that African liberation could not be complete until the new states continued to remain dependent 'from their former metropolis or from new expanding imperial powers', 1xiii denouncing the 'structural adjustments' imposed in the 1980 s by the IMF 'to control [their] economy and to intensify exploitation'. ${ }^{\text {xiv }}$ These adjustments implied that some corporations became "more powerful than states' ${ }^{\text {' } x v}$ and led to dramas that were not only social but environmental. On this point, de Andrade compared African decolonization to the previous Latin-American one; on both sides of the Atlantic, political independences had not been enough to avoid economic dependency and neocolonialism.

For de Andrade, Brazil faced the dilemma of whether to be 'a Third World country or an appendix to capitalism, ${ }^{\text {lxvi }}$ which shows that de Andrade, like de Castro, had some alignment with Tricontinentalism as defined by Mahler. Additionally, he envisaged a role for race in Third World alliances, defining Brazil as 'a mestizo country, with a large percentage of Blacks and persons of mixed race [having] possible affinities with African peoples'. lxvii However, according to de Andrade, this result could happen under the condition that Brazilian officials respected peoples who had freed themselves instead of trying to establish new tutelages. For the geographer, post-dictatorship Brazil was giving positive signals, such as its condemnation of Apartheid and the indication of racism as a crime in the 1988 Constitution, but also negative ones due to its nature as 'a minor partner, one which is controlled by big powers'. 1xviii

As I explain below, these positions can roughly summarize some decades of critical geographers' reflexions promoted by de Andrade's friends de Castro and Santos, who were more directly involved with African issues and equally hoped that Brazil could play a 'Third World' anti-racist and anti-colonial solidarity role, a wish that the successive (democratic or dictatorial) governments of their country rendered ineffective, at least at the level of official politics.

\section{Decolonizing a hungry world}

The figure of Josué de Castro has been recently rediscovered in international scholarship as a forerunner of critical geopolitics and of critiques to Malthusianism and Northern-driven ideas on development. ${ }^{\text {lxix }}$ Before being exiled in Paris by the military dictatorship from 1964 until

F. Ferretti, 2020, "Subaltern connections: Brazilian critical geographies and African decolonisation", The Third World Quarterly, early view: https://www.tandfonline.com/doi/full/10.1080/01436597.2020.1722095 
his death in 1973, de Castro was an important academic and political figure in Brazil; he was internationally renowned for his works on geographies and geopolitics of hunger, Chair of Geography in the Federal University of Rio de Janeiro, member of the Federal Parliament and Brazilian representative in international organizations such as the FAO and the United Nations in Geneva. ${ }^{\text {lxx }}$ As his works show, anti-colonialism and direct engagement with African scholars, leaders and activists, characterized his career before and after the 1964 breakup.

A Pernambucan like de Andrade, de Castro was an early campaigner in favour of the Recife mocambos, informal settlements mainly occupied by nonwhite citizens and menaced by violent eviction by the 'official pickaxe' ${ }^{\text {xxi }}$ Anticipating later elaborations of MCD authors, ${ }^{1 x x i i}$ de Castro's analysis of colonialism included critiques to the internal colonialism of Brazilian elites at the expense of Indigenous and Afro-descendants, acknowledging the centrality of the colonial question with statements such as 'The Northeast is a colony of the South [of Brazil], which is a colony of the United States, as in the past Brazil was a colony of Portugal, which was a colony of England' lxxiii North American neocolonialism in Latin America was one of the main problems that he addressed during his political career, also playing a primary role in the international solidarity campaigns for the Cuban revolution. ${ }^{\text {lxxiv }}$ De Castro had a special taste for ironically reverting the official rhetoric of development, arguing that 'there are no underdeveloped peoples, but only [countries] dominated by more powerful states ${ }^{\text {, } 1 \times x v}$ and claiming that the United States was the true 'underdeveloped country' due to the social contradictions of its society. ${ }^{1 x x v i}$

European colonialism (and later neocolonialism) in Africa was likewise a central concern in de Castro's activities. A 1956 parliamentary discourse on the Suez crisis is especially revealing of his thinking and actions. On that occasion, de Castro claimed a geopolitical role for Brazil, one that could be described under the label of a postcolonial 'subaltern geopolitics', lxxvii soliciting a Brazilian intervention in that affair to support a possible contingent of the United Nations. In his speech, de Castro expressed a clear anti-colonial philosophy inserting the French-British intervention in Egypt in the wider history of 'modern imperialist colonialism'. For de Castro, 'England and France are simply repeating an oft-practiced act of force and arrogance to enslave the weaker peoples, to exploit them, to maintain this unhuman economy [called] colonialism which saddens, depresses and degrades the human species'. ${ }^{\text {xxviii }}$ In his analysis, de Castro

F. Ferretti, 2020, "Subaltern connections: Brazilian critical geographies and African decolonisation", The Third World Quarterly, early view: https://www.tandfonline.com/doi/full/10.1080/01436597.2020.1722095 
linked decoloniality in the Americas and in Africa by tracing lines of continuity between the Spanish-Portuguese Conquista and the colonialism of his day, arguing that: 'Colonialism always acted in this way, since its beginnings ... with the occupation by the Europeans of countries where peoples called "barbarians" or "savages" lived ... In America the colonizers came bringing the cross and the sword ... to seek gold and to enslave those peoples'. ${ }^{\text {xxix }}$ De Castro continued his historical excursus by condemning the British colonial politics in India and then in Egypt, arguing for 'Egypt for Egyptians'. Calling for a generalized anti-colonial revolt, he clarified that he was not only criticizing French-British imperialism: 'I talk of all kinds of imperialism against which all the peoples of the world are rising now ... against British imperialism, against American imperialism, against Russian imperialism' ${ }^{1 \times x x}$ This antiRussian remark was related to the revolt in Hungary, with which de Castro expressed explicit solidarity and positions akin to those of 'nonaligned countries'. These positions stood out for their social and political radicality, evoking a model of decolonial development far from 'the old criminal ideas of Malthus', 'xxxi a model that called for 'the revolt of coloured peoples'. lxxxii

In his parliamentary discourses, de Castro evoked similar de-colonial concerns about Brazil and Latin America, for example with the Northeast, which he considered a sort of miniature 'Third World' within Brazil due to the permanence of an 'economy of colonial type'lxxxiii based on dependency on manufactured goods produced in the South of the country. He eventually argued for rethinking pan-Americanism by rediscovering its original spirit of "nationalism and anti-imperialism' and its alliance with the 'revolution of coloured peoples' 'xxxiv These ideas led to concrete engagement with Africa, as in 1960, when de Castro participated in the preparation of diplomatic missions in Africa and advocated for more-active Brazilian politics in favour of decolonization. ${ }^{\operatorname{lxxv}} \mathrm{He}$ also stated before the Brazilian press that the Bandung conference 'marked the revolt of the proletarian nations of the world' lxxxvi These statements show how radically de Castro matched the 'Bandung spirit', anticipating tricontinentalism and fostering a key role for Afro-Brazilian decolonial cooperation, especially in the African countries still dominated by the Portuguese.

De Castro returned to the importance of international conferencing for a decolonial agenda in a paper titled 'From Bandung to New Delhi, the great crisis of the Third World' and published in 1968, when he was already exiled and performed an informal kind of geopolitics through

F. Ferretti, 2020, "Subaltern connections: Brazilian critical geographies and African decolonisation", The Third World Quarterly, early view: https://www.tandfonline.com/doi/full/10.1080/01436597.2020.1722095 
associations such as the Paris CID (Centre International pour le Développement). ${ }^{\text {lxxuvii }}$ De Castro continued to analyse international conferences through anti-colonial lenses; the occasion was the Second United Nations Conference on Trade and Development celebrated in New Delhi in January 1968. The title alluded to de Castro's perception when facing the increasing situation of poverty, social injustice and political authoritarianism that recentlydecolonized countries experienced despite the great hopes that accompanied the process of decolonization. For the Brazilian geographer, 'It is no longer possible to deny that, despite the efforts accomplished by proletarian peoples since the Second World War, the fosse which divides the rich and industrialized countries from the poor and underdeveloped ones continues to enlarge. Reducing this divide ... seems a utopian task'. ${ }^{\text {lxxxviii }}$ The Third World was in crisis as a notion of resistance that is, in de Castro's definition, the hopes of 'peoples which had recently obtained their political independence and the others who were still struggling for their national sovereignty'. In this sense, the notion of development was associated with emancipation from 'colonial exploitation'. ${ }^{x x x i x}$ For de Castro, Bandung was the place where this awareness had been expressed, determining 'a key date in the history of the world's political evolution', including encouraging the rising of African nations.

Conversely, Delhi came in the middle of the disappointing period called 'decade of development' (1960-1970) by the United Nations, during which performances were well below the expectancies declared. De Castro attributed this deficiency to the classical mistakes of Western technocrats, who "consider the process of development as everywhere similar to the development of rich Western countries,' based on 'a sort of ethnocentrism' that led them to 'overlook completely the inhabitants of these regions, and traditional cultures' ${ }^{x c}$ Importantly, de Castro emphasized cultural differences and humanistic/humanitarian values against Western 'biological fatalism or geographical determinism,' arguing that the main cause of underdevelopment was 'political and economic colonialism' ${ }^{x c i}$ For de Castro, the 2,500 delegates from 132 countries who met in Delhi failed to reach any effective agreement on economic aid or possible reformations of international markets because the rich countries could take advantage of the dissensions existing among the poor ones. However, he argued that the economic failure of Delhi might lead to a potential success in political terms, mentioning those countries that wanted 'to defend a policy of total nationalization of their natural resources, which is the only way to free themselves from foreign [markets]'. xcii

F. Ferretti, 2020, "Subaltern connections: Brazilian critical geographies and African decolonisation", The Third World Quarterly, early view: https://www.tandfonline.com/doi/full/10.1080/01436597.2020.1722095 
Therefore, a possible comparison between Bandung and Delhi resided in the guess that both conferences had few economic immediate outcomes, but Bandung had important political consequences in the following years, and the same could be true with Delhi. For de Castro, 'it was Europe which paid the price of Bandung, losing its colonial empire', and it was possible that the Delhi conference proved a decisive step 'in the weakening of the North American economic empire, which now dominates the world economy'. ${ }^{x c i i i}$ While these judgements look rather simplistic from the standpoint of current scholarship, they well express de Castro's anticolonial tricontinentalism and result in more-general challenges to the American empire, which culminated in the international campaigns in favour of the Vietnamese guerrilla.

In 1964, de Castro lost his institutional appointments, but a strong continuity characterizes the anti-colonial content of his formal 'pre-golpe' diplomatic work as a Brazilian politician and ambassador and his later activities. In 1963, de Castro gave an inflamed speech at the FAO in Rome requesting a more political role for the FAO and claiming the imminent 'extinction'xciv of colonialism. In June 1964, already devoid of his political rights in Brazil, he attended the 'Mediterranean Conferences' in Florence, siding with exponents of the anti-colonial insurgent movements of Angola and Mozambique, a conference where the methods of European (and eventually Portuguese) occupants were explicitly defined 'fascism'. ${ }^{\mathrm{xc}}$ In France, de Castro was likewise acquainted with a number of anti-colonial exiled activists and recently empowered African leaders.

A first provisional list of his acquaintances among these political leaders includes Léopold Senghor, Kwame Nkrumah and Houari Boumédiène for Africa and many others for the 'Souths' in general (including Salvador Allende, Juan Peron, Fidel Castro and Pandit Nehru). In 1969, de Castro was invited to the First Pan-African Cultural Festival, organized by President Boumédiène in Algiers with the declared aim of pursuing cultural decolonization. From that meeting, a collaboration started between the Algerian government and de Castro's CID. ${ }^{\mathrm{xcvi}}$ During his French exile, other de Castro's initiatives involving post-colonial African leaders included the proposal of a World Peace District, which received the approval of the King of Morocco for the nomination of the city of Tangiers, deemed by de Castro 'the door of Africa and of the Mediterranean', ${ }^{x c v i i}$ to shelter there 'a certain number of international

F. Ferretti, 2020, "Subaltern connections: Brazilian critical geographies and African decolonisation", The Third World Quarterly, early view: https://www.tandfonline.com/doi/full/10.1080/01436597.2020.1722095 
organizations working for peace'. ${ }^{\text {xcviii }}$ Another initiative was the proposal of an International University of Development, for which Senghor wrote directly to de Castro from Dakar endorsing this institution, which would have been very useful 'to stop brain draining towards the United States'. xcix

From 1969 to 1973, de Castro was appointed Associate Professor of Geography at the University of Vincennes, an institution that gathered a great concentration of leftists and 'French Theorists' including among others Yves Lacoste, Michel Foucault and François Lyotard. ${ }^{\mathrm{c}}$ In de Castro's syllabi, whose copies survive in the Recife archives, one finds titles such as 'Black Africa. Geography of decolonization and of continental integration', ${ }^{\text {ci }}$ which reveals that de Castro believed in pan-African perspectives, even though he was aware of the large challenges that these projects faced. In these years, he collaborated with several French intellectuals committed to African decolonization such as agronomist Réné Dumont ${ }^{\mathrm{cii}}$ and anticolonialist geographer Jean Suret-Canale, active contributor to Guinean independence. ${ }^{\text {ciii }}$ Author of a preface for Suret-Canale's book La Faim dans le Monde, ${ }^{\text {civ }}$ de Castro corresponded with the French geographer in his late years, revealing the existence of a common project of the two geographers (not then accomplished due to de Castro's death) to publish 'a book on socialism and hunger' ${ }^{\mathrm{cv}}$ In his directory, the Brazilian exile kept a list of French geographers directly engaged against colonialism, such as Jean Dresch and Jean Le Coz (both active in Morocco), or interested in various ways in Third World topics, such as Pierre Gourou, Jacqueline Beaujeu-Garnier, Pierre Monbeig and Olivier Dollfuss, among others. ${ }^{\text {cvi }}$ These networks show how scholarly geography could be considered a socially and politically prickly discipline despite claims for its 'inoffensiveness'. ${ }^{\text {cvii }}$

\section{From "French Africa" to Tanzania}

Another figure only recently rediscovered in the international literature, ${ }^{\text {cviii }}$ Milton Santos is doubtlessly the most famous of critical and radical Brazilian geographers and a very popular figure in Brazil, although parts of his work remain understudied. This point is true of his relation to Africa and African decolonization, despite his well-known commitment to a scholarly programme on critical development led by Third World authors and his experience at the University of Dar es Salaam, where he taught from 1974 to $1976 .{ }^{\text {cix }}$ Moreover, Santos was a Black person from the state of Bahia; he denounced on several occasions the lasting

F. Ferretti, 2020, "Subaltern connections: Brazilian critical geographies and African decolonisation", The Third World Quarterly, early view: https://www.tandfonline.com/doi/full/10.1080/01436597.2020.1722095 
racism in Brazilian society, albeit race was never his main concern in relation to other social issues such as class. ${ }^{\text {cx }}$ This section is a first attempt to clarify this matter by drawing upon Santos's writings and unpublished archives.

An early Santos book, little-known even in Brazilian scholarship, can provide a first help to address these matters. Published in 1960, Marianne em preto e branco [Marianne in Black and White] collects Santos's reportage from his first travels in France and Western Africa in 1957 and 1958, which were funded with a research grant that he obtained due to his $\mathrm{PhD}$ supervisor Jean Tricart, then professor in Strasbourg. These recollections, first published in the Bahia newspaper $A$ Tarde, of which Santos was director for a period, ironically address the experience of a Black man in Europe, one whose Afro-Brazilian background was characterised by the entangled conflicts of race, class and culture later discussed by Denise Ferreira da Silva. ${ }^{\text {cxi }}$ Santos discovered places that he had highly mythized and did not even hope to visit, but he also witnessed the contradictions of a complex society and of a colonial empire that was entering the process of decolonization.

Santos considered this situation a paradox, arguing that imperialist France helped 'young Africa' ${ }^{\text {cxii }}$ to build its independence. This idea recalls classical postcolonial literature on the role of European education in the formation of decolonizer elites, ${ }^{\text {cxiii }}$ consistently with Santos's socialistic universalism. However, race also played a role in his thinking, as is apparent in his interpretation of the principles of the French revolution, when he fumed at 'the prejudices which separate the rich and the poor, the black and the whites' ${ }^{\text {cxiv }}$ Importantly, once in Strasbourg, Santos's immediate admiration for the French public university system was expressed in anti-colonial terms for his Brazilian public; he argued that only higher education could allow 'nations to reach a complete independence'. ${ }^{\mathrm{cxv}}$ While such remarks were first related to the debates concurrently promoted by de Castro on Latin America's liberation from neocolonialism, they clearly included an implicit reference to Africa.

In his reportages, Santos tried to revert the traditional colonizer's gaze from North to South by addressing, for his readers, the social issues of the different French regions that he had the occasion to visit, from the problems of social housing to the miserable conditions of Spanish and Italian migrant workers. He was especially interested in some marginal regions of

F. Ferretti, 2020, "Subaltern connections: Brazilian critical geographies and African decolonisation", The Third World Quarterly, early view: https://www.tandfonline.com/doi/full/10.1080/01436597.2020.1722095 
Southeastern France, which somehow recalled to him the 'savage' landscape of Northeastern Brazil, as 'historical shelter for bandits' in the Camargue case and 'land of misery' in the case of Lozère. This comparison became explicit when he translated French toponym La Brousse as Sertão, that is, the poor and marginalized backlands of the Northeast.

The last part of the book relates Santos's journey to West Africa, at the very sunset of direct French rule over it. Key in Santos's discussions were the economic relations between Brazil and Sub-Saharan Africa, which seemed already to be of interest to the Brazilian public in the 1950s, originating neologisms such as 'Afro-Brasilia'cxvi and Brazilian concerns for African competition in fields such as the production of cacao. For Santos, there was no 'African peril' for the Brazilian economy but only a 'domestic peril', that is 'overproduction' cxvii His argument was a classical socialist one; as 'few are the beneficiaries of this kind of

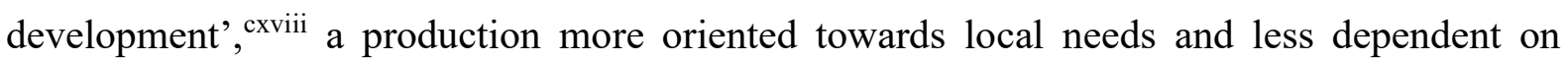
Northern capitalistic markets would have led to a solution of the problem. In its simplicity, this argument not only attacked colonial and neocolonial dependency but also questioned the entire economic system based on market and profit, where the prize of a product counts more than its real use value.

Santos spent a few weeks between Senegal, Ivory Coast and Mali in the middle of the enormous extension of so-called Afrique Occidentale Française. His interest was first directed to endemic poverty and to the 'abuses ${ }^{\text {'cxix }}$ suffered by local peasants, but he also gave attention to the 'ethnic variety' ${ }^{\mathrm{cxx}}$ and local solidary customs that the geographer defined as a traditional 'habit of mutual aid'cxxi on a communitarian basis, practiced within the networks of migrants from the hinterland to coastal cities such as Dakar. For Santos, the capital of Senegal showed the results of a 'brutal clash of civilizations', ${ }^{2 x i i}$ where the European one was represented by the large trade companies. While Santos did not escape stereotypes of his (mainly) European education such as ideas on the 'quietness' of the African civilization, he could not ignore the phenomena of hybridity and cosmopolitanism that characterized colonial cities, accompanied by cultural vivacity and social unrest that made him suppose that he was 'assisting the lively elaboration of a new world'. ${ }^{\text {xxiii }}$ The impression is that here Santos constantly alluded to decolonization without explicitly naming it, probably as a form of prudence from someone who was officially travelling as a guest of the French government.

F. Ferretti, 2020, "Subaltern connections: Brazilian critical geographies and African decolonisation", The Third World Quarterly, early view: https://www.tandfonline.com/doi/full/10.1080/01436597.2020.1722095 
Santos's final visit to Bamako gave him the opportunity to stress the historical links between West Africa and Brazil, especially Bahia and the Northeast. 'This country talks a lot to a Brazilian possibly unsure of his genealogical tree ... A boy ... tells me that I am actually at home'. ${ }^{\text {cxxiv }}$ In metropolitan France, an ironic anecdote told by Santos showed a different local perception of race; seated in a bar chatting in Portuguese with two white Brazilian colleagues, Santos was flabbergasted by seeing an elderly French gentleman approaching and congratulating his interlocutors, claiming that he had never seen French people so proficient in an 'African dialect' as they were. ${ }^{\text {cxxv }}$ White necessarily meant French, and Black necessarily meant African!

During his return flight, Santos coincidentally met Jean Dresch, already mentioned as de Andrade's friend and supporter. This meeting inaugurated his acquaintance with international radical geographers interested in African decolonization. A particularly eminent one was David Slater, a Santos's colleague in Tanzania who remained his close friend and collaborator. ${ }^{\text {cxxvi }}$ In the mid-1970s in Dar es Salaam, Santos and Slater contributed to what Jo Sharp has recently called the 'postcolonial geopolitical imaginations' fostered by president Julius Nyerere. As shown by Sharp, higher education was a key point for Nyerere's decolonial strategy, and the University was accordingly 'established as a postcolonial site of learning'. cxxvii What matched Santos's programme for the South 'theorizing back', in Slater's definition, ${ }^{\text {cxxviii }}$ was the idea of rendering sub-Saharan Africa a place for the production and spreading of original knowledge rather than vulgarization of Western notions, to 'posit an alternative geopolitical imagination from the margins ${ }^{\text {cxxix }}$ of the Cold War.

Importantly, Sharp notices that, consistent with this idea of decolonization, foreign teachers were assumed to be temporary to allow local scholars taking over from them once they went home, as Santos and Slater did. Yet, Santos's archives show that not all his colleagues were happy with this solution. For instance, a Nigerian colleague, Osita C. Eze, wrote to the Brazilian geographer complaining about the possible sacking of academic personnel not due to compliance with this programme but rather to the fact that 'the atmosphere has continued to deteriorate in Dar [and] about $20 \%$ of the civil servants have been declared redundant from the $20^{\text {th }}$ February' ${ }^{\text {cxxx }}$ Of course, this university experience could not be exempted from facing the

F. Ferretti, 2020, "Subaltern connections: Brazilian critical geographies and African decolonisation", The Third World Quarterly, early view: https://www.tandfonline.com/doi/full/10.1080/01436597.2020.1722095 
economic and political challenges that led to crisis of several national African projects at that time. ${ }^{\text {cxxxi }}$

Santos's case confirms Sharp's remark that the University of Dar es Salaam, for which Nyerere took directly responsibility as vice chancellor, "was not a simple case of Westernized knowledge coming to Tanzania and colonizing debates; many of the Western academics and the debates they took back home were profoundly Tanzanian-ized'. ${ }^{\text {cxxii }}$ In a letter to the University Dean Albert Temu, sent when Santos was already in Brazil, the geographer attributed this effect directly to the Tanzanian leader. 'I rethink what I have learned in your extraordinary country. Believe me, my sojourn there marks a definitive turning point in my way of thinking about space and conceiving my discipline. [I send two copies of my paper] because one of them I would like you to give to President Nyerere, to whom I told, one day, that he was the best of geographers because of his understanding of the fact that to change a country, we have first to change its space. Only we have to be careful about the possibilities of changing space from the outside and to serve outside targets'. ${ }^{\text {cxxiii }}$ This paper was probably Santos's contribution on socio-spatial formations, ${ }^{\text {cxxxiv }}$ published in a special issue of Antipode, that he co-edited with Richard Peet in 1977. Santos intended the paper as a means of giving voice to Third World authors, ${ }^{\text {cxxx }}$ confirming the importance of Africa for this project and the impact of the Tanzanian experience in informing key points of Santos's thinking, including the notion of 'shared space' that was elaborated in these years. ${ }^{\text {cxxxvi }}$

Other letters from previous Dar es Salaam colleagues to Santos reveal the importance of African decolonial university experiences for the English-speaking circuits of radical geographers in the 1970s. Ben Wisner, one of the founders of Antipode when he was a graduate student in Clark in $1969,{ }^{\text {cxxxvii }}$ wrote in Portuguese to his 'querido colega e companheiro' Santos from newly decolonized Mozambique in 1978, alluding to his experience of many years 'of effective engagement with the problems of African development ... in Kenya, Tanzania and now Mozambique', ${ }^{\text {cxxviii }}$ requesting from Santos some hints to publish a paper on Mozambican national construction in some Brazilian journal. What is significant in this document is the direct commitment of Anglo-American scholars to South-South intellectual cooperation, even using languages other than English, and to possible Afro-Brazilian connections.

F. Ferretti, 2020, "Subaltern connections: Brazilian critical geographies and African decolonisation", The Third World Quarterly, early view: https://www.tandfonline.com/doi/full/10.1080/01436597.2020.1722095 
Another friend and colleague involved in Santos's African experience was again a historical Antipode editor, Joe Doherty, whose works on Tanzania likewise inspired Santos. ${ }^{\text {cxxxix }}$ In 1978, Doherty wrote a long letter from Freetown, Sierra Leone to Santos, telling how he was 'back in Africa after three years ... but on the wrong side', ${ }^{\text {cxl }}$ indicating the interest of critical and radical geographers in contributing to African socialism. Conversely, to Doherty, Freetown looked more like a 'capitalist city' than 'Dar'. Among several problems with poverty, sanitation and lack of any planning, Doherty noticed 'that racial segregation became an established feature of the town's growth', ${ }^{\text {cxli }}$ stressing the problem of the country's dependence on foreign capitals and imports, given also the lack of local industries and the 'few token import substitution activities'. This observation again indicates an interest in solutions suggested by dependency theorists, such as developing Third World manufactures to alleviate dependency.

In Santos's biography, an episode of 1977 highlights the concreteness of an 'African' solution for a Southern intellectual banished from his country; an offer to teach in the University of Port Harcourt (Nigeria) came through one of the friends whom he had known in North America, sociologist Claude Ake. Milton accepted with the intention, expressed in a letter to Ake, to later appoint other colleagues there to establish a 'future geography department' ${ }^{\text {cxlii }}$ that would have been led by him. The folder of the institutional correspondence between Santos and the Port Harcourt officers shows that negotiations reached a very advanced stage. ${ }^{\text {cxliii }}$ However, at the last minute, Santos decided not to go because he had the possibility of returning to Brazil, where he would finally establish himself as Chair of Geography at the University of São Paulo but would not lose interest with respect to Afro-Brazilian scholarly relations.

These included until the present-day projects such as the University of International Integration of Afro-Brazilian Lusophony (UNILAB), founded in 2010 in the context of the politics of South-South cooperation promoted by the governments Lula and Dilma, in the Northeastern town of Redenção, the first that abolished slavery in Brazil. ${ }^{\text {cxliv }}$ Yet, recent scholarship by Susanne Ress alerts on the dangers of heroizing these experiences, highlighting tensions, contradictions and similarities with North-South discourses in Brazilian South-South cooperation. ${ }^{\text {cxlv }}$

F. Ferretti, 2020, "Subaltern connections: Brazilian critical geographies and African decolonisation", The Third World Quarterly, early view: https://www.tandfonline.com/doi/full/10.1080/01436597.2020.1722095 


\section{Conclusion}

This paper has shown the radicality, albeit not devoid of some contradictions and limitations, of anti-colonial geographical traditions by analysing little-known cases on the axis of SouthSouth activism and intellectual cooperation and, eventually, the engagement with Africa of key figures in Brazilian critical geography. At the same time, this paper has highlighted the importance of the Northeastern origin of these geographers in informing their interest in antiracist issues, in analysing different forms of colonialism (imperialism, neocolonialism, and internal colonialism) and in the need for including local cultures in social projects for the 'Souths', anticipating later critiques of neo-colonialist notions of development.

The above also sheds light on the perception of international Third World conferencing in the decades of decolonization by radical Southern intellectuals. While their positions classically oscillated between hope and disappointment, they continued their collaboration with African experiences in different ways, from de Castro's CID initiatives to Santos's teaching in Africa. Recent studies generally acknowledge that conferences such as Bandung were more important for their indirect results than for their immediate outcomes. Likewise, it is possible to argue that the work of Brazilian critical and exiled geographers still has the potentiality for nourishing current debates beyond the relative lack of effectiveness of their immediate interventions, given the positions of marginality that they suffered during most of their respective careers.

Finally, while this paper further demonstrates that geographical traditions go well beyond the imperial cultures that many 'classical' geographers served, it also shows that it is possible to (at least partially) respond to the numerous calls to decolonize the discipline by looking at its 'other' traditions. This should include research on materials revealing the generous attempts for producing original knowledge in the Global South performed by Milton Santos, Manuel Correia de Andrade, Josué de Castro and many others within their cosmopolitan, multilingual and transnational networks.

\footnotetext{
i Carter, "Population"; Davies, Josué; Ferretti and Viotto, "Inventing”; Ferretti, “A coffin”; Melgaço, "Thinking”; Melgaço and Prouse, "Milton". All quotes from texts originally in Portuguese, Spanish or French have been translated by the author.

ii Dodds, "The Third World".

iii Ferretti, "Decolonizing"; Hecht, The Scramble.

iv Driver, Geography; Bell, Butlin and Heffernan, Geography; Livingstone, The Geographical Tradition.

${ }^{\vee}$ Sachs, Dictionary; Escobar, Territories.

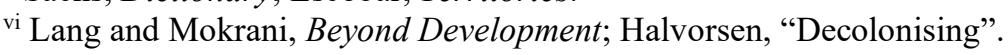

F. Ferretti, 2020, "Subaltern connections: Brazilian critical geographies and African decolonisation", The Third World Quarterly, early view: https://www.tandfonline.com/doi/full/10.1080/01436597.2020.1722095 
vii Power, Geopolitics.

viii Castro, Geography.

${ }^{\text {ix }}$ Craggs and Wintle, Cultures.

${ }^{x}$ Craggs, "Postcolonial", 40.

xi Schwarz, "Black America", 30.

xii Hodder, "Toward a geography"; Featherstone, "Black Internationalism".

xiii Gilroy, The Black Atlantic; Shilliam, The Black Pacific.

xiv Cheong, "A subaltern", 2.

xv Cheong "A subaltern", 2.

xvi Chimni "Anti-Imperialism”, 35.

xvii Eslava, Fakhri and Nesiah, Bandung, 4.

xviii Eslava, Fakhri and Nesiah, Bandung, 17.

xix Chatterjee, "The legacy", 657.

${ }^{x x}$ Mahler, From the Tricontinental, 7.

xxi Mignolo, "The Global South".

xxii Mahler, From the Tricontinental, 39.

xxiii Mahler, From the Tricontinental, 65.

xxiv Mahler, From the Tricontinental, 240.

xxv Davies, Josué.

xxvi Radcliffe, "Decolonising"; Esson et al., "The 2017"; Naylor et al. "Interventions".

xxvii Barnes and Sheppard, Spatial Histories.

xxviii Jazeel and Legg, Subaltern Geographies.

xxix Slater, Geopolitics, 116.

xxx Grosfoguel, "Towards a decolonial”.

xxxi Césaire, Discours.

xxxii Castañeda, Resistencia, 9.

xxxiii Tuck and Wayne Young, "Decolonisation", 9.

xxxiv Coulthard, Red Skin, 5.

${ }^{x x x v}$ Maldonado Rivera and Valle Rojas, "Episteme decolonial”, 322

xxxvi Rivera, Ch'ixinakax utxiwa, 62

xxxvii Lao-Montes, "Las actuales insurgencias", 173.

xxxviii Mançano-Fernandes and Porto-Gonçalves, Josué de Castro.

xxxix Ferretti, "Decolonizing".

${ }^{x l}$ Andrade, Abolição.

xli Andrade, Elisée Reclus.

xlii Andrade, O Nordeste, 57.

xliii Andrade, História, 11.

xliv Andrade, $O$ Brasil, 13.

xlv Andrade, $O$ Brasil, 17.

xlvi Andrade, O Brasil, 19.

xlvii Araújo, O Fio, 118.

xlviii Ferretti, "Radical Development".

xlix Andrade, O Brasil, 23.

' Andrade, O Brasil, 26.

li Andrade, $O$ Brasil, 26.

lii Andrade, O Brasil, 38.

liii Andrade, $O$ Brasil, 40.

liv São Paulo, Instituto de Estudos Brasileiros (hereafter IEB), MCA(Caixa 33), Andrade to Jair Levi, 14 December 1968; 5 February 1969.

lv Andrade, $O$ Brasil, 42.

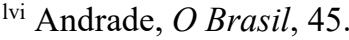

lvii Andrade, O Brasil, 57.

lviii Andrade, O Brasil, 61.

lix IEB, MCA-GEOPOL-001, O sentido da colonização.

lx Andrade, $O$ Brasil, 65.

lxi Andrade, O Brasil, 65.

lxii Slater, Geopolitics.

F. Ferretti, 2020, "Subaltern connections: Brazilian critical geographies and African decolonisation", The Third World Quarterly, early view: 
lxiii Andrade, O Brasil, 63.
lxiv Andrade, O Brasil, 66.
lxv Andrade, O Brasil, 67.
${ }_{\text {Ixvi Andrade, O Brasil, } 69 .}$
1xvii Andrade, O Brasil, 69.
1xviii Andrade, O Brasil, 76.
lxix Carter, "Population"; Davies, "Unwrapping"; Ferretti, “A coffin".
1xx Ziegler, "Betting".
lxxi Recife, Fundação Joaquim Nabuco, Coordenação-Geral de Estudos da História Brasileira, JCo (hereafter CEHIBRA), 349, "Um higienista defende os mucambos de Recife contra a picareta official". A Tarde, 23 November 1938.

lxxii Mignolo and Escobar, Globalization.

lxxiii CEHIBRA, 5, Jornal do Comércio, 12 December 1960.

lxxiv CEHIBRA, 5, “O Sr. de Castro volta de Cuba e fala de Cuba”, Diário Carioca, 18 January 1961.

lxxv CEHIBRA, 112, Ultimas Noticias [Caracas], 19 August 1968.

lxxvi CEHIBRA, 314, USA - Pais subdesenvolvido.

lxxvii Sidaway, Mamadouh and Power, "Reappraising".

Ixxviii CEHIBRA, 705, Suez, 3.

lxxix CEHIBRA, 705, Suez, 4.

${ }^{\text {lxxx }}$ CEHIBRA, 705, Suez, 6.

lxxxi CEHIBRA, 705, Suez, 9.

Ixxxii CEHIBRA, 705, Suez, 10.

1xxxiii CEHIBRA, 705, Operação Nordeste.

lxxxiv CEHIBRA, 705, Reformulação do panamericanismo.

lxxxv CEHIBRA, 5, Jornal do Comércio, 11 June 1960.

lxxxvi CEHIBRA, 5, Jornal do Comércio, 12 December 1960.

lxxxvii Davies, Josué.

Ixxxviii CEHIBRA, 277, De Bandung a Nova Delhi, a grande crise do terceiro mundo [orig. in Revue Générale Belge, April 1968].

lxxxix CEHIBRA, 277, Bandung.

${ }^{x c}$ CEHIBRA, 277, Bandung.

xci CEHIBRA, 277, Bandung.

xcii CEHIBRA, 277, Bandung.

xciii CEHIBRA, 277, Bandung.

xciv CEHIBRA, 224, FAO Meeting, 23 November 1963.

${ }^{\mathrm{xcv}}$ CEHIBRA, 224, Le colloque méditerranéen, Rome 6 July1964.

${ }^{x c v i}$ CEHIBRA, 424, Premier Festival Culturel Panafricain; 622, Castro to Moussauoi, 30 June 1969; Castro to Ben Yahia, 4 August 1969.

xcvii CEHIBRA, 167, Castro to Mhammedi, 18 January 1965.

xcviii CEHIBRA, 34, Mhammedi to Castro, 9 February 1965.

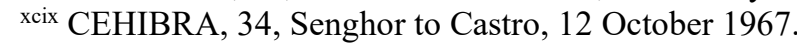

${ }^{\mathrm{c}}$ Djian, Vincennes.

ci CEHIBRA, 190, Tiers Monde et sous-développement [1969].

cii CEHIBRA, 96, "Un débat au cercle des études africains", Le Monde, 26 May 1966.

ciii Suret-Canale, De la Résistance.

civ Mouchel and Suret-Canale, La Faim.

${ }^{\mathrm{cv}}$ CEHIBRA 386, Castro to Suret-Canale, 15 October 1971.

cvi CEHIBRA 510, Liste contacts.

cvii Lacoste, La Géographie.

cviii Melgaço, "Thinking"; Ferretti and Viotto, "Inventing"; Davies, "Milton".

cix Contel, "Milton".

cx Cirqueira, "A questão".

cxi Silva, "Bahia".

cxii Santos, Marianne, 6.

cxiii Chakrabarty, Provincialising.

cxiv Santos, Marianne, 6.

cxv Santos, Marianne, 10.

F. Ferretti, 2020, "Subaltern connections: Brazilian critical geographies and African decolonisation", The Third World Quarterly, early view: 


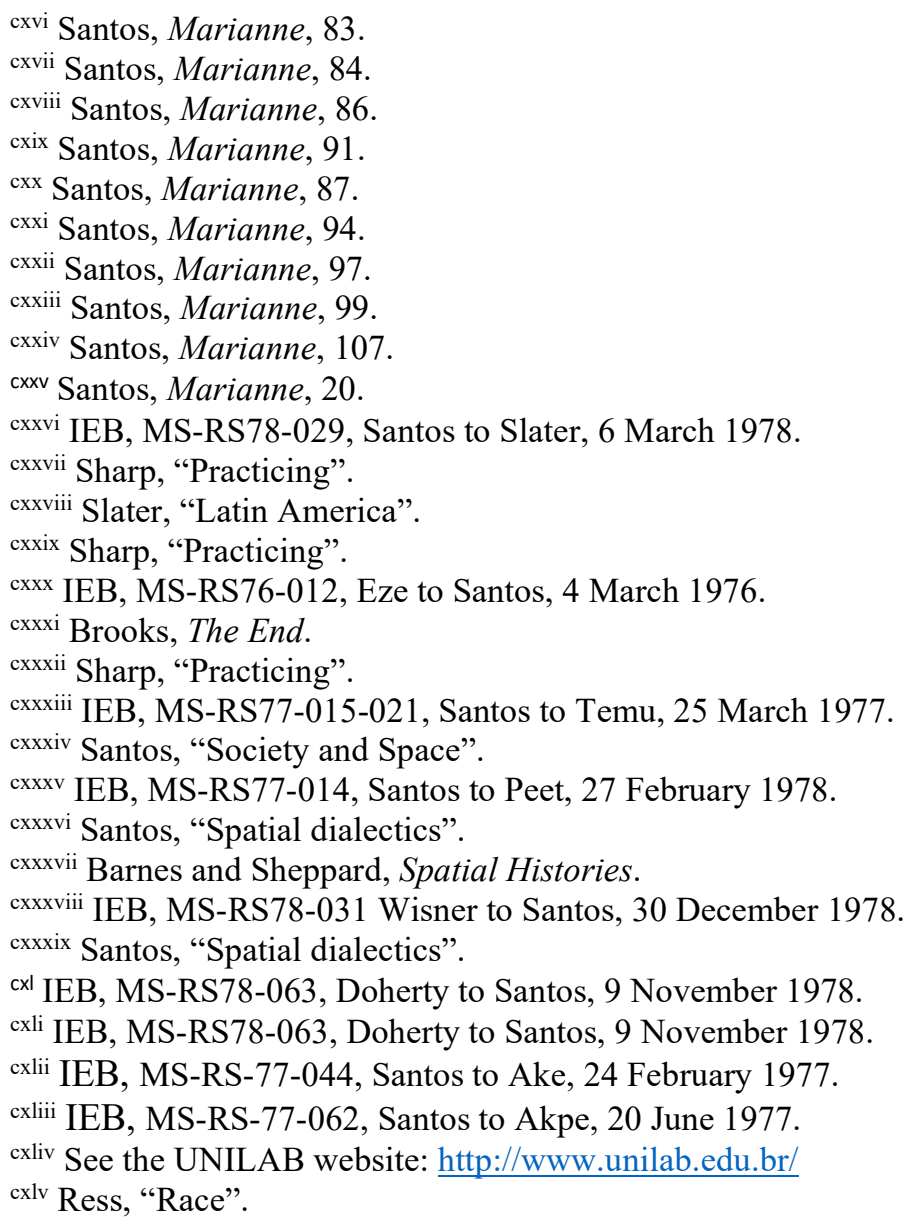

\section{References}

Andrade, Manuel Correia. Elisée Reclus, geografia. Sao Paulo: Ática, 1985.

Andrade, Manuel Correia. Lutas camponesas no Nordeste. São Paulo: Ática, 1986.

Andrade, Manuel Correia. O Nordeste e a Nova Republica. Recife: ASA, 1987.

Andrade, Manuel Correia. História das usinas de açucar de Pernambuco. Recife: Fundaj, 1987.

Andrade, Manuel Correia. Abolição e reforma agrária. São Paulo: Ática 1991.

Andrade, Manuel Correia. O Brasil e a Africa. São Paulo: Contexto, 1991 ( $2^{\text {nd }}$ ed).

Araújo, Rita. O fio e a trama. Depoimento de Manuel Correia de Andrade. Recife: UFPE, 2002.

Barnes, Trevor and Eric Sheppard (eds.). Spatial Histories of Radical Geography: North America and Beyond, Hoboken, Wiley, 2019.

F. Ferretti, 2020, "Subaltern connections: Brazilian critical geographies and African decolonisation", The Third World Quarterly, early view: 
Bell, Morag, Butlin, Robin and Michael Heffernan (eds.). Geography and imperialism 18201940. Manchester: Manchester University Press, 1995.

Brooks, Andrew. The End of Development: A Global History of Poverty and Prosperity. Chicago: University of Chicago Press, 2017.

Carter, Eric. "Population control, public health, and development in mid twentieth century Latin America”. Journal of Historical Geography 62 (2018): 96-105.

Castañeda Sifuentes, Yulissa, Resistencia de los pueblos indígenas mayas ante la deforestación en Guatemala. Valencia: Cuadernos de investigación en procesos de desarrollo (21), 2018.

Castro, Josué. Geography of Hunger. London: Gollancz, 1952,

Césaire, Aimé. Discours sur le colonialisme. Paris: Réclame, 1950.

Chakrabarty, Dipesh. Provincializing Europe: Postcolonial Thought and Historical Difference. Princeton: Princeton University Press, 2000.

Chatterjee, Partha. "The legacy of Bandung". In Bandung, Global History, and International Law, edited by Luis Eslava, Michael Fakhri and Vasuki Nesiah, 657-674. Cambridge: Cambridge University Press, 2017.

Cheong, Sharon. “A Subaltern Geopolitics?”. Geopolitics (2019) early view: https://doi.org/10.1080/14650045.2019.1588525

Chimni, Bhupinder. "Anti-Imperialism then and now". In Bandung, Global History, and International Law, edited by Luis Eslava, Michael Fakhri and Vasuki Nesiah, 35-48. Cambridge: Cambridge University Press, 2017.

Cirqueira, Diogo. “A questão negra na trajetória teórica do geógrafo Milton Santos”. In Anais do XVI Encontro Nacional dos Geógrafos. Porto Alegre: AGB, 2010, 1-11.

Contel, Fábio. "Milton Santos”. In Intérpretes do Brasil, edited by Lincoln Secco and Luiz Bernardo Pericas, 393-409. São Paulo: Boitempo, 2014.

Coulthard Glenn. Red Skin, White Masks: Rejecting the Colonial Politics of Recognition, Minneapolis: University of Minnesota Press, 2014.

Craggs, Ruth. "Postcolonial geographies, decolonization, and the performance of geopolitics at Commonwealth conferences". Singapore Journal of Tropical Geography, 35 (2014): 39-55. Craggs, Ruth and Claire Wintle (eds.). Cultures of Decolonisation, Transnational Productions and Practices, 1945-70. Manchester: Manchester University Press, 2016.

Davies, Archie. "Milton Santos: The conceptual geographer and the philosophy of technics". Progress in Human Geography, 43, 3 (2019): 584-591.

F. Ferretti, 2020, "Subaltern connections: Brazilian critical geographies and African decolonisation", The Third World Quarterly, early view: https://www.tandfonline.com/doi/full/10.1080/01436597.2020.1722095 
Davies, Archie. "Unwrapping the OXO Cube: Josué de Castro and the intellectual history of metabolism". Annals of the American Association of Geographers, 109, 3 (2019): 837-856.

Davies, Archie. Josué de Castro's Geografia Combatente and the political ecology of hunger. $\mathrm{PhD}$ thesis. King's College London, 2019.

Djian, Jean-Michel (ed.). Vincennes, une aventure de la pensée critique. Paris: Flammarion, 2009.

Driver, Felix. 2001, Geography Militant. London: Blackwell, 2001.

Dodds Klaus, "The Third World, developing countries, the South, poor countries". In The Companion to Development Studies, edited by Vandana Desai and Robert Potter, 3-7. London: Hodder, 2008.

Escobar, Arturo. Territories of Difference: Places, Movements, Lives. Durham: Duke University Press, 2008.

Eslava, Luis Fakhri Michael and Vasuki Nesiah, (eds.). Bandung, Global History, and International Law. Cambridge: Cambridge University Press, 2017.

Esson, James, Noxolo, Patricia, Baxter, Richard, Daley, Patricia and Margaret Byron. "The 2017 RGS-IBG chair's theme: decolonising geographical knowledges, or reproducing coloniality?" Area 49, 3 (2017): 384-388.

Featherstone, David. "Black internationalism, anti-fascism and the makings of solidarity". Soundings: A Journal of Politics and Culture, 55 (2013): 94-107.

Ferretti, Federico. "Geographies of internationalism: radical development and critical geopolitics from the Northeast of Brazil”. Political Geography, 63 (2018): 10-19.

Ferretti, Federico. “A coffin for Malthusianism: Josué de Castro's subaltern geopolitics". Geopolitics, (2019) early view:

https://www.tandfonline.com/doi/full/10.1080/14650045.2019.1583213

Ferretti, Federico. "Decolonising the Northeast: Brazilian subalterns, non-European heritages and radical geography in Pernambuco". Annals of the American Association of Geographers, 109, 5 (2019): 1632-1650.

Ferretti, Federico and Breno Viotto Pedrosa. "Inventing critical development: a Brazilian geographer and his Northern networks". Transactions of the Institute of the British Geographers, 43, 4 (2018): 703-717.

Gilroy, Paul. The Black Atlantic: Modernity and Double Consciousness. London: Verso, 1993.

F. Ferretti, 2020, "Subaltern connections: Brazilian critical geographies and African decolonisation", The Third World Quarterly, early view: https://www.tandfonline.com/doi/full/10.1080/01436597.2020.1722095 
Grosfoguel, Ramón. “Towards a decolonial transmodern pluriversalism”. Tabula Rasa 9 (2008): 201-215.

Halvorsen, Sam. "Decolonising territory: Dialogues with Latin American knowledges and grassroots strategies". Progress in Human Geography (2018), early view, doi: $10.1177 / 0309132518777623$

Hecht, Susanna. The Scramble for the Amazon and the 'Lost Paradise' of Euclides da Cunha. Chicago: The University of Chicago Press, 2013.

Hodder, Jake. "Toward a geography of Black Internationalism: Bayard Rustin, nonviolence and the promise of Africa". Annals of the American Association of Geographers, 106, 6 (2016): $1360-1377$.

Jazeel, Tariq and Stephen Legg (eds). Subaltern Geographies. Athens: University of Georgia Press, 2019.

Lacoste, Yves. La geographie, ça sert d'abord a faire la guerre. Paris: Maspero, 1976.

Lao-Montes Agustín. "Las actuales insurgencias políticas-epistémicas en las Américas: giros a la izquierda, giros anti imperiales, giros de-coloniales". Comentario Internacional, 7 (2007): $173-185$

Lang, Miriam and Dunia Mokrani (eds.). Beyond Development. Alternative Visions from Latin America. Amsterdam: Transnational Institute, 2013.

Livingstone, David. The Geographical tradition. Oxford: Blackwell, 1993.

Mahler, Anne Garland. From the Tricontinental to the Global South, Race, Radicalism, and Transnational Solidarity. Durham and London, Duke University Press, 2018.

Maldonado Rivera, Claudio and Carlos del Valle Rojas. "Episteme decolonial en dos obras del pensamiento mapuche: reescribiendo la interculturalidad”. Chungara, Revista de Antropología Chilena, 48, 2 (2016): 319-329.

Mançano-Fernandes, Bernardo and Carlos-Walter Porto-Gonçalves (eds). Josué de Castro, vida e obra. São Paulo: Expressão Popular. 2007.

Melgaço, Lucas. "Thinking outside the bubble of the Global North: introducing Milton Santos and 'the active role of geography'". Antipode, 49, 4 (2017): 946-951.

Melgaço, Lucas and Carolyn Prouse (eds.). Milton Santos: Pioneer in Geography. London: Springer, 2017.

Mignolo, Walter, "The Global South and world dis/order". Journal of Anthropological Research, 67, 2 (2011): 165-188.

F. Ferretti, 2020, "Subaltern connections: Brazilian critical geographies and African decolonisation", The Third World Quarterly, early view: https:/www.tandfonline.com/doi/full/10.1080/01436597.2020.1722095 
Mignolo, Walter and Arturo Escobar (eds.). Globalization and the Decolonial Option. London: Routledge, 2010.

Mouchel, Jean-Claude and Jean Suret-Canale. La Faim dans le monde. Paris: Données, 1969. Naylor, Lindsay, Daigle, Michelle, Zaragocin, Sofia, Ramírez, Margaret M. and Mary Gilmartin. "Interventions: Bringing the decolonial to political geography". Political Geography, 66 (2018), 199-209.

Power, Marcus. Geopolitics and Development. Abingdon: Routledge, 2019.

Radcliffe, Sarah. "Decolonising geographical knowledges". Transactions of the Institute of British Geographers, 42, 3 (2017): 329-333.

Ress, Susanne. "Race as a political issue in Brazilian South-South Cooperation in higher education". Comparative Education Review, 62, 3 (2018): 409-428.

Rivera Cusicanqui, Silvia, Ch'ixinakax utxiwa, una reflexión sobre prácticas y discursos descolonizadores. Buenos Aires: Tinta Limón, 2010.

Sachs, Wolfgang (ed.). The Development Dictionary, a Guide to Knowledge as Power. London: Zed Books, 1992.

Santos, Milton. Marianne em preto e branco. Bahia: Progresso, 1960.

Santos, Milton. "Society and space: social formation as theory and method". Antipode, 9, 1 (1977): 3-13.

Santos, Milton. "Spatial dialectics: the two circuits of urban economy in underdeveloped countries”. Antipode, 9, 3 (1977): 49-60.

Schwarz, Bill. "Black America and the overthrow of the European colonial order: The tragic voice of Richard Wright". In Cultures of decolonisation, Transnational productions and practices, 1945-70, edited by Ruth Craggs and Claire Wintle, 29-50. Manchester: Manchester University Press, 2016.

Sharp, Joanne. "Practicing Subalternity? Nyerere's Tanzania, the Dar School, and Postcolonial Geopolitical Imaginations". In Subaltern Geographies edited by Tariq Jazeel and Stephen Legg, 74-93. Athens: University of Georgia Press, 2019.

Shilliam, Robbie. The Black Pacific: Anti-colonial Struggles and Oceanic Connections. London: Bloomsbury, 2015.

Sidaway, James, Mamadouh, Virginie and Marcus Power. "Reappraising geopolitical traditions". In The Ashgate Research Companion to Critical Geopolitics, edited by Klaus Dodds, Merje Kuus and Joanne Sharp, 165-187. Farnham: Ashgate, 2013.

F. Ferretti, 2020, "Subaltern connections: Brazilian critical geographies and African decolonisation", The Third World Quarterly, early view: https://www.tandfonline.com/doi/full/10.1080/01436597.2020.1722095 
Silva, Denise Ferreira. "Bahia Pêlo Negro. Can the subaltern (subject of raciality) speak?”. Ethnicities 5 (2005): 321-342.

Slater, David. Geopolitics and the Post-colonial: Rethinking North-South Relations. Malden: Blackwell, 2004.

Slater, David. "Latin America and the challenge to imperial reason". Cultural Studies 25 (2011): 450-458.

Suret-Canale, Jean. De la Résistance à l'anticolonialisme: entretiens autobiographiques recueillis et présentés par Pascal Bianchini. Paris: l'Esprit frappeur, 2011.

Tuck, Eve and K. Wayne Yang. "Decolonization is not a metaphor". Decolonization: Indigeneity, Education \& Society 1 (2012): 1-40.

Ziegler Jean. Betting on Hunger. Why the world still Goes Hungry. New York/London: The New Press, 2013.

F. Ferretti, 2020, "Subaltern connections: Brazilian critical geographies and African decolonisation", The Third World Quarterly, early view: 